\section{PENGARUH POLA-POLA AKADEMIK DALAM PERKEMBANGAN PATUNG MODERN DI KECAMATAN UBUD}

I Ketut Buda

FSR InstitutSeni Indonesia Denpasar

email: ktbuda@yahoo.com

\section{Abstrak}

Perkembangan seni patung modern dengan berbagai bentuk dan gaya yang tumbuh di Bali umumnya dan di Kecamatan Ubud Khususnya, lebih mengarah pada tampilan yang minimalis. Perkembangan seperti ini tidak terlepas dari pengaruh pariwisata yang mulai banyak meminati seni patung modern Balisebagai barang souvenir. Bahkan seni patung modern di Bali telah menjadi produk unggulan yang telah dipasarkan ke berbagai negara, sehingga volume permintaan seni patung cukup pesat. Bahkan Seni Patung dalam perkembangannya hampir menjadi produk kerajinan yang berkembang di berbagai wilayah di Bali, terutamanya di Kecamatan Ubud dan sekitarnya.

Apabila diperhatikan secara mendalam, munculnya patung modern yang minimalis di masyarakat tidak jauh berbeda dengan karya-karya modern yang ada di lingkungan akademik, sebagai proses pembelajaran. Banyak karya-karya piguratif yang lahir di kalangan akademik sebagai modifikasi dari bentuk-bentuk realis maupun dekoratif yang berkembang di masyarakat. Penyederhanaan bentuk yang melahirkan karya patung minimalis awalnya hanya lahir di kalangan akademik, tetapi sekarang sudah menjadi sebuah barang kerajinan yang diproduksi oleh masyarakat luas.

Dalam penelitian ini akan mengkaji secara mendalam, bagaimana peranan akademik dalam pengembangan kerajinan patung modern yang ada di masyarakat. Apakah perkembangan tersebut karena dipengaruhi oleh akademik atau pengaruh para pengusaha asing yang memberikan contoh sebagai barang pesanan kepada para perajin, kemudian diproduksinya dalam jumlah banyak. Bagaimana peranan perajin dalam proses kreatifnya, apakah hanya menunggu pesanan atau atas kreatifnya sendiri, kemudian menjajagkan pada pengusaha asing.

Kata kunci: Pola akademik, patung modern.

\section{Abstract}

It is only recently that many modern sculptures developed with various shapes and styles that lead more to minimalist looks. This development is inseparable from the influence of tourists that began to feel interested in modern Balinese statues assouvenirsto take hometo their native countries. Indeed, modern
Pengaruh Pola-pola Akademik dalam Perkembangan ... (I Ketut Buda) Balinese statues have become flagship products that will be marketed in a country, and consequently the demand volume of those statues increased rapidly. Statues have become handicrafts developed indifferent areas, especially in Ubud and surroundingdistricts.Upon an in-depth consideration, the emergence of modern minimalist statues in the society is not pretty much different from those progressed in academic settings as a learning process. Many figurative works emerged from academic setting asmodifications of other realistordecorative works that flourishin society. The simplification of shapes that gave birth tothe minimalist art statues only existed initially inacademic setting, butnow they have become handicraft items produced by public. This study examines comprehensively how the academics play their role in the development of modern art and sculpture craft in the community. Do these developments a rise because of academic influence or of the influence of foreign businessmen who provided samples to the craftsmen, who thenproduced them inlarge volumes? What role do the artisans play inthese developments? Are they just waiting for the order or being creativeto create new work and offered them to the foreign businessmen?

Keywords: Academic pattern, modern statues

\section{PENDAHULUAN}

Seni patung adalah salah satu karya seni rupa Bali yang tidak terlepas dari gempuran pengaruh pariwisata yang berkembang di Bali. Masuknya pariwisata diBali, mengubah orientasi penciptaan karya seni patung yang awalnya dilandasiuntuk memenuhi kebutuhan spiritual menjadi penciptaan seni patung untukmemenuhi kebutuhan sekuler. Dengan perubahan orientasi ini banyak patungimitasi yang bermunculan, karena banyak wisatawan yang tertarik pada patungBali yang berbentuk dewa-dewa maupun binatang mitologi.

Perubahan yang paling mendasar pada seni patung sebagai dampak daripariwisata adalah penciptaan seni patung merupakan media ekspresi seorangseniman dengan menjunjung tinggi kebebasan.Para pematung tidak lagi terikatdalam menciptakan patung dewa-dewa dengan pakem-pakem tertentu, tetapimereka sudah bebas berkreasi sesuai dengan ide dan gagasanya sendiri.

Ketika kebebasan berekspresi menjadi tuntutan dalam sebuah penciptaankarya seni patung, membuka ruang yang lebih leluasa bagi seniman patung untukberinovatif dalam berkarya di atas landasan tradisi yang sangat kuat.Seni tradisimenjadi dasar pijakan berkreasi sesuai dengan ide dan gagasan seorang seniman.

Gerusan pariwisata temyata menjadi ajang kompotisi bagi seniman patung untuk menunjukan dirinya sebagai seorang seniman yang penuh dengan ide dangagasan dalam penciptaan. Dengan landasan tematik agama Hindu dan 
Budaya Bali menjadi konsep dasar penciptaan dengan pengolahan bentuk dan gaya menjadi sebuah karya baru yang sangat indah dan menarik. Totalitas seniman dalam berkarya masih kuat mengakar, melekat, satu dan padu pada karya yangdiciptakan.

Tidak dapat dipunggkiri bahwa segala sesuatunya akan mengalam perubahan sesuai dengan perkembangan jaman, ilmu dan teknologi termasuk Sen patung sebagai sebuah karya seni. Penciptaan seni patung bukan saja sebagai media ekspresi, tetapi merupakan sebuah ketrampilan untuk menopang kehidupan sehari-hari sebagai sebuah karya seni kerajinan yang diproduksi secara massal dan dipasarkan di pinggirjalan.

Terciptanya seni patung sebagai karya kerajinan, bukan berarti hilangnya kreasi dalam penciptaan tersebut. Kreasi penciptaan justru semakin berkembang sejalan dengan tuntutan persaingan yang semakin ketat. Kompetisi untuk menciptakan disain baru menjadi suatu keharusan agar tidak ketinggalan dengan orang lain. Karya seni patung baru akhirnya bermunculan yang diangkat dari kearifan lokal dan dikembangkan menjadi karya baru yang disebut dengan karya modern.

Sebagai sebuah karya seni kerajinan dan merupakan barang eksport, maka dalam penciptaan karya seni patung tidak saja mempertimbangkan keindahan karya tersebut, tetapi juga mempertimbangkan hal-hal lain seperti: praktis, ergonomis, estetis, dan ekonomis. Keunikan bukan menjadi suatu tuntutan, tetap keindahan dan harmoni merupakan hal yang teramat penting dewasa ini. Tuntutan penciptaan karya seperti ini akhimya bermunculan karya-karya seni patung modern dengan bentuk yang minimalis.

Pada awalnya karya-karya seni patung minimalis muncul di kalangan akademik. Penerapan struktur pendidikan yang sistematis yang dilandasi dengan penerapan nilai-nilai estetika dalam penciptaan, maka terciptalah karya seni yang sederhana dengan nilai seni yang tinggi. Dengan dilandasi konsep penciptaan yang sangat matang, seorang mahasiswa harus dapat menginterprestasi sebuah obyek penciptaan dengan melahirkan metafora baru. Sebuah obyek tidak harus dimunculkan secara utuh, tetapi dapat dimunculkan dengan metafora yang baru yang sesuai dengan ide dan gagasan seniman. Dengan konsep berkarya seperti in maka lahirlah karya-karya baru dengan bentuk minimalis dengan kandungan makna yang sangat mendalam.

Didukung oleh kebiasaan meniru yang sangat kuat oleh para perajin Bali, banyak karya-karya patung minimalis yang diciptakan sebagai barang kerajinan. Konsep dasar penciptaanya tidak jauh berbeda dengan seni tradisi, tetapi sekarang telah diwujudkan secara sederhana. Rama Sita yang dulunya dibuat sangat unik, sekarang telah dirubah proporsinya atau disederhanakan dengan wujud yang sangat polos, namun kesan asmaranya masih sangat kuat.
Kecamatan Ubud merupakan salah satu sentra berkembangnya seni patung modern di bali. Salah satu desa yang sebagian besar penduduknya sebagai pematung adalah Desa Mas. Di luar Desa Mas, karya patung modern juga banyak berkembang di Desa Peliatan, Singakerta, dan Desa Petulu. Dari empat desa ini akan dijadikan obyek penelitian tentang pengaruh pola-pola akademik dalam penciptaan seni patung modern.

\section{KAJIAN PUSTAKA \\ Pengertian Patung}

Seni patung adalah salah satu dari perwujudan sculpture disamping relief. Dalam Ensiclopedia Britania (1968:vol 20) dijelaskan bahwa Sculpture may be broadly defined as the art of representing observed or imagined objects in solid materials and in three dimension. There are two generals types: 1. Statuary, in which figures are shown in the round. 2. Relief, in which figures project from a grounds". Dari kutipan di atas dinyatakan bahwa sculpture itu adalah karya seni yang dapat damati dari wujud tiga dimensi (trimatra). Ada dua tipe yang termasuk sculpture adalah: 1. Patung, yang dapat diamati dari segala sisi, 2. Relief, motifnya menonjol dari sebuah bidang datar (flat beckground).(Richadrdson, 1980: 353) bahwa "Patung dapat dilihat dari berbagai arah (freestanding statues) dan berbeda dengan relief yang tidak dapat dilihat dari berbagai arah"

Seni patung terwujud dalam tiga dimensi, yaitu adanya kedalaman bentuk,

bidang, dan ruang. Bentuk pada seni patung merupakan perwujudan seni rupa yang paling kongkrit yang dapat diterima oleh indera manusia. Bentuk patung adalah utuh, tidak ada sudut yang tidak luput dari penglihatan, tidak ada bagian sekecil apa pun yang tersembunyi. Bentuk patung mempunyai rupa yang dapat dipandang, dapat disentuh, diraba, dapat pula dirasakan gerak iramanya melalui lekuk cembungnya volume.(Mochtar, 1992: 23).

Seni patung merupakan pemyataan pengalaman artistik lewat bentukbentuk tiga dimensional. Pada galibnya seni patung adalah tiga dimensional dengan demikian benar-benar berada di dalam ruang. Seni patung dapat dibagi menjadi dua yaitu seni patung aditif seperti membutsir dan seni patung subtraktif misalnya seni pahat kayu dan batu, dalam hal bentuk dan fungsinya menjadi patung penuh (en ronde-bosse) dan relief tinggi (haut relief), relief rendah (bas relief), relief sedang (demi relief), patung mandiri (free-standing), dan patung terikat. (Soedarso, 2006: 98)

Berdasarkan uraian di atas dapat dijelaskan bahwa seni patung adalah karya seni rupa dalam wujud tiga dimensional yang memiliki bentuk, ruang, bidang, volume, sehingga dapat dilihat dari berbagai arah dan diekspresikan dalam bergagai material seperti kayu, batu, logam, tanah liat, dengan teknik pahat, butsir, cetak dan konstruksi. 


\section{Seni Patung Bali}

Seni patung Bali telah ada sejak lama dan kelahirannya lebih banyak dikaitkan dengan kebutuhan kepercayaan yang memiliki nilai magis. Seni patung bali memiliki berbagai istilah sesuai dengan bentuk dan fungsinya seperti: Togog, Arca, Pretima, dan Bedogol. Arca merupakan wujud dewa-dewi yang penggambarannya sebagai manusia atau binatang Arca dan Pretima merupakan perwujudan Dewa dan Bhatara dalam bentuk patung yang digunakan sebagai sarana konsentrasi dalam persembahyangan .Arca ukurannya lebih besar, bahannya dari kayu pilihan seperti: cendana, cempaka, dan majagau. Pretima umumnya lebih kecil dan dibuat dari emas, perak, uang kepeng dan lainnya. Pretima juga sering disebut Prelingga, atau Petapakan yaitu tempat berstananya para dewa yang merupakan sinar suci dari Ida Sanghyang Widhi Wasa.

Bedogol adalah patung yang dibuat dari batu, batu padas, ataupun kayu, biasanya dibuat dengan ukuran yang agak besar, sangat sederhana dan memiliki fungsi penjaga. Bodogol biasanya berwujud menyeramkan, mata mendelik, hidung besar, berkumis dengan membawa senjata dan memiliki karakter yang galak dan pemberani, sehingga memiliki kesan yang sangat magis.

Togog adalah patung yang berfungsi sekuler yaitu sebagai dekoratif atau fungsional untuk memenuhi kebutuhan jasmani dan rohani manusia. Togog merupakan seni patung yang tidak terikat oleh pakem tertentu, sehingga dapat berubah dan dikembangkan sesuai dengan ekspresi penciptanya. (Linus dalam Buda, 2009).

Seni patung Bali telah tumbuh sejak jaman pra sejarah dimana manusia belum mengenal tulisan. Bukti peninggalan patung ini dapat dilihat di Desa Trunyan Kintamani yang diberi nama Ratu Gede Pancering Jagat. Patung in sangat tinggi yaitu 5 meter dengan bentuk muka yang sangat menyeramkan. Masyarakat setempat memujanya sebagai perwujudan nenek moyang yang telah memberikan kedamaian dan kesejahteraan. (Sutha, 2007: 84).

Masuknya agama Hindu dan Budha ke Bali, seni patung Bali mengalami perkembangan yang sangat pesat karena difungsikan sebagai sarana keagamaan sebagai personipikasi dan Dewa-dewa yang menjaga dunia dengan alam semesta Munculah bentuk patung Dewa-dewa atau binatang mitologi yang sering disebut dengan Pretima banyak dikeramatkan pada tempat-tempat suci baik untuk masyarakat umum maupun masyarakat kecil.

\section{Seni Patung Bali Modern}

Ada dua kata kunci dalam pengertian seni patung modern yaitu: "bentuk" dan "kreatif" But Muchtar menjelaskan bahwa bentuk pada seni patung merupakan perwujudan seni rupa yang paling kongkrit dapat diterima oleh indra manusia; bentuk patung adalah utuh, dan tidak ada bagian yang tidak dapat dilihat oleh indera mata, tidak ada bagain sekecil apapun dari patung yang luput atau tersembunyi. (Soedarso, 1992: 23)

(Erfahmi, 2007: 19): Ditinjau dari perkembangan corak rupa seni patung modern, melalui proses kreatif seniman, pada awalnya terjadi pergeseran dari realis yang menyalin bentuk secara obyektif menjadi penyederhanaan bentuk, bahkan dalam perjalanan gaya seni patung muncul abstrak dan seterusnya. Semakin jauh jangkuan imajinasi, ide dan konsep tentang seni patung yang ditandai dengan kreativitas yang tak kenal batas. Bentuk semula yang diwujudkan melalui proses dipahat (carving), butsir (modeling), dicetak (casting), dan dirakit (constructing), sampai pada patung bergerak, berbunyi dan sebagainya.

Penciptaan karya seni patung modern Bali disebabkan pengaruh dari seniman luar yaitu Walter Spies, Rudolf Bonnet, yang ditandai dengan perubahan orientasi dan fungsi patung itu sendiri dari yang bernilai religius menjadi sekuler. Kelahiran karya seni merupakan gejolak ekspresi seorang seniman yang ingin menciptakan suatu karya sesuai dengan ide dan gagasannya yang divisualisasikan dalam sutau media seperti kayu, batu, logam dan sebagainya. Tentunya penciptaan ini memiliki kebebasan baik bentuk, teknik, dan material namun tetap memiliki kemurnian ide dan gagasan seorang seniman sehingga karya tersebut tetap memiliki jiwa dan roh yang sangat kuat.

Pariwisata memberikan dampak yang sangat besar terhadap perkembangan seni patung modern bali. Banyak para wisatawan yang ingin memiliki karya seni baliyang sangat unik dan artistik yang memiliki fungsi dan non fungsional. Pariwisata juga menyebabkan orientasi penciptaan karya seni patung mengalami perubahan yang cukup signifikan yaitu dari seni regilius menjadi karya seni sekuler, dan karya seni murni menjadi karya seni kerajinan.

Selain karena pariwisata, terciptanya karya seni patung modem juga tidak terlepas dari pengaruh perkembangan ilmu dan teknologi. Banyak peralatan teknologi yang mendukung ekspresi seniman dalam berkarya, terutama dalam mengadakan berbagai eksperimen yang berkaitan dengan teknik dan material yang digunakan. Teknologi dengan segala perangkatnya sering memberikan inspirasi pada pematung untuk mengadakan eksperimen dalam usaha menemukan alternatif baru dalam proses penciptaan.

\section{Pendidikan Seni Rupa di Bali}

Perkembangan seni patung di Bali tidak terlepas dari proses pendidikan yang dilakukan baik secara formal maupun non formal. Seni merupakan salah satu bagian yang sangat penting dalam kehidupan masyarakat Bali yang banyak dibutuhkan dalam kehidupan beragama Hindu dan telah berkembang di masyarakat. Melihat pitalnya kebutuhan seni di Bali yang perlu dikembangkan dan dilestarikan, maka merasa perlu dibuka pendidikan formal pada seni tersebut. 
Pendidikan formal seni rupa di Bali dimulai sejak tahun 1956 di Singaraja yang bernama "Rupa Datu". Pendidikan seni ini bersifat umum yang mempelajar semua bidang seni rupa seperti seni lukis, seni patung, seni kriya dan yang lainnya.

Pada tahun 1967 berdiri pendidikan seni rupa negeri di Denpasar yaitu Sekolah Menengah Seni Rupa (SMSR) negeri Denpasar. Pendidikan menengah seni rupa ini bertujuan untuk memberikan keahlian dalam penciptaan seni rupa sebagai bekal ketrampilan dalam pengembangan seni rupa. Lulusan yang diharapkan memiliki keahlian dibidang seni dan dapat mandiri sebagai pencipta seni dan dapat menghasilkan karya-karya yang kreatif dan inovatif.

Jenjang pendidikan memengah seni rupa dipandang kurang cukup untuk memepelajari karya seni karena seni sangat komplek dan berkembang. Pendidikan menengah seni rupa dianggap kurang cukup waktu dan hanya sebagai dasar ketrampilan dan belum mengarah pada penuangan ide, konsep dan gagasan. Pada tahun 1965 didirikanlah Program Seni Rupa di Universitas Udayana di bawah naungan Fakultas Teknik. Drs A.A Rai Kalam adalah salah satu pendiri program seni rupa di UNUD dengan gigih dan tekun menggembleng mahasiswa untuk lebih aktif dalam mengkaji dan mencipta karya seni. Banyak anak lulusan sekolah menengah seni atau sekolah menengah umum yang melanjutkan pendidikan Mereka memilih berbagai jurusan sesuai minatnya yaitu jurusan seni lukis, seni patung, seni kriya, dan disain.

Berdirinya pendidikan seni rupa formal di Bali, penciptaan seni rupa mengalami perkambangan yang cukup pesat. Karya seni tidak saja berkembang di masyarakat, tetapi juga di sekolah-sekolah dan perguruan tinggi seni. Demikian juga halnya dalam pengembangan seni patung banyak muncul di akademik terutama patung modern dengan berbagai teknik dan material.

\section{Pola-Pola Akademik}

Pendidikan akademik memiliki sistem pendidikan yang terstruktur dan sistemati baik dalam teori maupun praktikum. Materi pelajaran teori dan praktikum selalu berkaitan dan saling mendukung. Sebagai dasar pengetahuan seni terutama dalam penciptaan dilandasi oleh pola-pola akademik yang tertuang dalam teori estetika dan teori penyusunan. Dalam penciptaan karya seni secara umum selalu berpatokan pada pola-pola tersebut agar karya tersebut memiliki nilai estetika yang tinggi.

Pola-pola akademik yang dimaksudkan di sini adalah proses penciptaan karya seni yang berlandaskan pada unsur-unsur estetika dan prinsip-prinsip penyusunan. Dalam pendidikan akademik, sebelum menciptakan karya seni harus mempertimbangkan garis, warna, ruang, bidang, tekstur, juga komposisi, proporsi, irama, kesatuan, keseimbangan, harmoni, dan pusat perhatian. Segala karya sen rupa dalam proses penciptaannya selalu mempertimbangkan langkah-langkah ini.
Dalam pendidikan akademik sebagai proses pembelajaran, langkah ini menjadi dasar pengetahuan dalam proses penciptaan karya seni.

Secara tidak langsung bagi seniman atau perajin dalam berkarya tentunya pola-pola akademik sudah mereka lakukan dengan baik, tetapi mereka belum memahami apa yang mereka kerjakan dan terkadang tidak semua langkah tersebut dilakoninya. Mereka selalu mengejar kekuatan teknik dan keunikan dalam berkarya dan mengganggap yang unik adalah yang terbaik. Dalam penciptaan karya modern yang sederhana, pola-pola di atas sangat penting untuk diperhatikan karena nilai seninya akan muncul dari pertimbangan tersebut.

\section{HASILPENELITIAN}

\section{Geografis Kecamatan Ubud}

Ubud adalah salah satu kecamatan di Kabupaten Gianyar yang wilayahnya sangat sejuk, indah, asri, nyaman unik dan alami. Sejarah Ubud tidak dapat dilepaskan dari perjalanan para Rsi dari Jawa ke bali. Dalam perjalanan sejarah Guru suci Mpu Markandya dari Gunung Raung Jawa ke Bali, dalam proses penyebaran Agama Hindu beliau tiba di sebuah lereng atau bukit kecil yang memanjang ke arah utara dan selatan. Bukit ini diapit oleh dua buah sungai yang berliku yang mirip seperti dua ekor naga. Sungai yang berada disebelah barat bernama Sungai Wos Barat, sedangkan yang berada disebelah timur bernama Sungai Wos Timur. Mpu Markendya mendirikan sebuah pemukiman disebut "Sarwa Ada" yang terletak disekitar desa Taro.

Sebutan Wos untuk kedua sungai yang telah bercampur ini melekat menjadi nama desa/pemukiman pada jaman itu. Sedangkan nama sungai ini sesuai dengan maknanya. Sesuai dengan isi lontar Markandya Purana, Wos ngaran "Usadi", Usadi ngaran "Usada", dan Usada ngaran "Ubad". Dari kata ubad ini ditranskripsikan menjadi UBUD. (Propil Kelurahan Ubud, 2007: 4).

Ubud merupakan suatu wilayah kerajaan kecil namun memiliki kepercayaan dan wibawa yang sangat besar pada masyarakatnya. Raja Ubud sangat memegang teguh kehidupan seni budaya dan agama yang bertujuan untuk mempersatukan masyarakat agar tidak tergerus oleh pengaruh budaya asing.

Seni dan agama merupakan dua wilayah yang selalu berkaitan dan saling mendukung, berjalan beriringan dengan segala aktivitasnya untuk menghasilkan budaya yang dianut oleh masyarakatnya sebagai budaya tradisi yang tidak bisa dilepaskan dari kehidupan sehari-hari. Raja Ubud menyadari bahwa seni dan agama Hindu merupakan dasar kehidupan masyarakat yang telah mendarah daging dari waktu ke waktu. Oleh sebab itu raja Ubud selalu berusaha untuk menempatkan seni dan Agama Hindu sebagai jembatan dalam menopang kehidupan masyarakatnya. 
Perekmabangan seni di Ubud di samping perhatian istana cukup besar, juga disebabkan karena dapat pengaruh dari beberapa seniman barat yang telah lama mencintai Ubud sebagai pusat seni di Bali. Beberapa seniman barat yang berperan sangat penting dalam perkembangan seni di Ubud adalah: Rodolf Bonnet, Wallter Spies, Antonio Balnco, Arie Smit, Han Snell, dan yang lainnya.

Ada perubahan yang cukup mendasar ketika seni rupa di Ubud mendapat pengaruh dari seniman barat. Perubahan itu adalah fungsi, tema, gaya, teknik, sert material yang digunakan. Karya seni yang diciptakan tidak saja berorientasi religius, tetapi juga sebagai seni sekuler. Seni sudah menjadi media ekspresi bagi seorang seniman dalam menciptakan karya seni. Tema yang diangkat tidak saja berkaitan dengan tema-tema mitelogi agama Hindu, tetapi sudah mengarah pada tema kehidupan sehari-hari. Karya seni tidak lagi dikerjakan secara kolektif, tetapi secara individu, sehingga pengakuan seni sudah personal. Pengaruh lain yang paling mendasar adalah masuknya anatomi dan perspektif dalam karya.

Seni patung merupakan salah satu karya seni rupa yang telah berkembang sejak lama di Ubud. Dalam lintasan sejarah perkembangan seni rupa modern bal khususnya seni patung diawali dari perkembangan seni patung yang ada di Ubud. Perkembangan ini tidak dapat dilepaskan dari pengaruh seniman barat yang sangat besar perhatiannya pada karya seni Bali pada waktu itu.

Rudolf Bonnet, seorang pelukis Belanda telah menetap di Bali sejak tahun 1928 dengan Walter Spies seorang pelukis Jerman dan Tjokorde Gede Agung Sukawati seorang bangsawan dari Puri Ubud pada tahun 1935 mendirikan perkumpulan pelukis dan pematung dengan nama "Pita Maha". Sejak saat itu sen lukis dan seni patung mulai menemukan bentuknya yang baru (Sidarta, 1975: 19). Di bawah naungan kelompok "Pita Maha" yaitu perkumpulan seni lukis dan seni patung.

Untuk melestarikan karya-karya seni kelompok Pita Maha, maka Puri Ubud mendirikan Museum Puri Lukisan tahun 1951 dibawah yayasan Ratna Warta Ubud. Berdirinya Museum Puri Lukisan membuka lebih luas Ubud sebagai obyek wisata. Banyak infrastruktur lainnya didirikan untuk mendukung pariwisata tersebut seperti hotel, bar, restoran, cotage, home stay serta sarana tranfortas lainnya. Banyak juga gallery, art shop yang menjajagkan berbagai karya seni rupa seperti seni lukis, seni patung, serta seni kerajinan lainnya. Didukung dengan promosi yang gercar akhirnya Ubud menjadi salah satu obyek wisata yang sangat terkenal.

\section{Perkembangan Seni Patung di Kecamatan Ubud}

Kecamatan Ubud terdiri dari satu kelurahan dan tujuh desa yaitu: Kelurahan Ubud, Desa Peliatan, Desa Mas, Desa Lod Tunduh, Desa Singakerta, Desa Sayan, Desa Petulu, dan Desa Kedewatan. Sebagian besar desa yang ada di
Ubud masyarakatnya menekuni penciptaan patung sebagai karya seni maupun kerajinan. Masing-masing desa menghasilkan karya patung yang beranekaragam dan berbeda antara yang satu dengan yang lainnya.

\section{Kelurahan Ubud}

Karya seni rupa yang lebih banyak berkembang di Kelurahan Ubud adalah Seni lukis. Yang menekuni seni patung sangat minim dan hanya berkembang di Banjar Junjungan. Sampai saat ini di Banjar Junjungan masih berkembang seni patung modern yang mengarah pada seni kerajinan yang menciptakan berbagai bentuk binatang, manusia motilogi dan sebagainya. Mereka lebih banyak menunggu pesanan yang ada dengan sekali-sekali menciptakan model-model baru.

Belakangan ini perajin di banjar Junjungan populasinya sangat jauh menurun. Mereka tidak bisa melanjutkan propesinya sebagai perajin. Banyak mereka kembali sebagai petani atau menjadi tukang bangunan. Hal ini disebabkan karena pesanan sudah sangat jauh menurun, harga bahan baku melambung tinggi, sementara harga barang justru menurun.

\section{Desa Peliatan}

Dalam perkembangan seni patung, desa Peliatan memiliki peranan yang cukup penting karena di desa ini bercokol beberapa seniman patung yang sangat terkenal serta memberikan kontribusi yang besar pada penduduk desa lainnya untuk mengembangkannya yaitu I Wayan Neka, I Wayan Ayun, I Nyoman Togog, I Wayan Sadu, I Wayan Winten dan yang lainnya.

Ketika pop art mulai berkembang, Desa Peliatan menjadi salah satu pusat terciptanya karya-karya pop art yang baru dengan segala variasinya. Sebagian besar masyarakat Peliatan menekuni karya ini di samping karya seni patung lainnya.

Tokoh pematung dari desa Peliatan yang belakangan ini cukup terkenal adalah I Wayan Winten yang merupakan tokoh muda yang lahir dari akademik. Keahliannya mematung di samping banyak didapat karena belajar di banjarnya sejak kecil, juga banyak dibentuk dari akademik terutama yang berkaitan dengan teknik, pemanfaatan bahan, kreasi dan sebagainya. Wenten mempunyai keahlian mematung dengan berbagai teknik dan material serta mempunyai kekuatan dalam bentuk dan anatomi. Wenten telah melahirkan karya-karya yang monumental yang tersebar luas di seluruh Bali. Wenten juga sangat produktif menciptakan karya patung murni dari kayu dengan gaya minimalis. Gaya patung minimalis akhirnya berkembang di masyarakat yang lebih sering disebut dengan patung abstrak dan diproduksi secara massal sebagai seni kerajinan. Winten juga banyak mempengaruhi para pematung dalam memanfaatkan teknologi yang ada, karena 
teknologi sangat membantu proses pengerjaan. Bagaimana menggunakan gergaj mesin dalam proses pembentukan dalam patung kayu diawali oleh Winten sendiri.

\section{Desa Mas}

Desa Mas menjadi pusat perkambangan seni patung yang ada di kecamatan Ubud bahkan di Bali. Sebagian besar masyarakat Mas menekuni sen patung sebagai pekerjaannya di samping bertani. Semua warga yang ada di Mas mengerjakan seni patung dengan berbagai bentuk dan jenis. Pekerjaan ini tidak terlepas dari lingkungan yang ada sehingga jenis patung tersebut terpusat padan satu banjar.

Ada dua tokoh yang berperan penting dalam pengembangan seni patu di Desa Mas yaitu Ida Bagus Nyana dan anaknya Ida Bagus Tilem. Dua tokoh in dianggap sebagai cikal bakal seni patung modern Bali. Dibawah bimbingan dua seniman barat yaitu Rodolf Bonnet dan Walter Spies mereka mulai menciptakan karya patung dengan penuh kebebasan dan tidak mau terikat dengan pakem-pakem seni klasik dan tradisional. Mereka mulai menciptakan patung tidak proporsional, merespon material yang ada menjadikan sebuah karya yang sesuai dengan ide dan gagasannya sendiri.

Di samping beberapa seniman di atas, pada masing-masing banjar juga banyak berkembang seni patung lainnya yang sifatnya produksi. Mereka menciptakan patung sesuai dengan permintaan. Masing-masing banjar memiliki jenis patung yang berbeda yaitu Banjar Juga banyak terdapat patung jenis burung, Banjar Kumbuh berkembang jenis patung telanjang, Banjar Bangkilesan berkembang patung abstrak, banjar Tegal Bingin berkembang patung topeng modern.

\section{Desa Petulu}

Desa Petulu adalah salah satu desa yang wilayahnya paling utara di kecamatan Ubud. Berkembangnya seni patung di Petulu tidak terlepas dari perkembangan seni patung yang ada di desa Mas dan desa Peliatan. Banyak warga petulu yang belajar mematung di Desa Mas maupun di Desa Peliatan. Warga banjar Nagi banyak yang belajar mematung di desa Peliatan dengan patung binatangnya, sedangkan warga Petulu Desa banyak yang belajar mematung di desa Mas. Banjar nagi akhirnya menjadi pusat pembuatan patung binatang seperti babi, gajah, kurakura, kuda dan sebagainya. Patung tersebut ada diciptakan dengan tambahan fungsi seperti untuk asbak, tempat botol dan sebagainya. Masyarakat Nagi juga banyak sebagai pengepul patung dan dipasarkan di pasar seni Sukawati.

Seni patung berkembang pesat di Petulu Desa adalah patung yogi. Semua pematung beralih mengerjakan patung yogi karena secara ekonomi nilainya cukup besar. Di samping patung yogi juga banyak yang memesan patung tangan yang difungsikan untuk kursi duduk. Lapangan kerja terbuka luas bagi semua masyarakat baik anak-anak, ibu rumah tangga dan yang lainnya. Banyak juga yang berasal dari luar daerah mencari pekerjaan membuat patung di Petulu Desa.

Hampir sama dengan desa lainnya, saat ini permintaan patung sudah sangat jauh menurun. Banyak pengepul patung yang gulung tikar karena sudah tidak bisa memproduksi lagi. Permintaan sudah menurun, harga jatuh, sedangkan harga kayu menjunjung mahal. Banyak pematung yang beralih pekerjaan menjadi buruh bangunan, bertani, atau bekerja lainnya.

\section{Desa Lod Tunduh}

Desa Lod Tunduh bertetangga dengan Desa Mas Jenis patung yang berkembang di Lod Tunduh adalah wajah hiasan seperti wajah rama, sita, rawana, serta bentuk topeng seperti topeng barong, karang sae, dan sebagainya. Bentuk wajah ini sangat mewah lengkap dengan gelungnya yang dikerjakan dengan ukiran yang unik. Kualitas patung ini sangat sempurna, wajah yang halus, bibir tersenyum, dan mata yang lentik. Bentuk topeng juga dikerjakan secara halus dan sempurna, muka yang galak dan menyeramkan.

Desa Lod Tunduh juga pernah menjadi sentral berkembangnya seni pop art sebagai barang kerajinan. Banyak kerajinan sketsel dan pigura cermin yang terbuat dari kayu ringan dengan finishing cat dijajagkan sepanjang jalur ini. Disain-disain baru berkembang dengan pesat seiring dengan banyaknya permintaan yang ada. Masyarakat cukup kreatif dan produktif untuk melayani segala permintaan. Kini kerajinan tersebut telah hilang tanpa bekas dan perajinan banyak beralih pada pekerjaan lainnya. Yang masih cukup berkembang di desa Lod Tunduh kerajinan topeng modern.

\section{Desa Singekerta}

Desa Singekerta adalah salah satu desa di kecamatan Ubud yang memiliki wilayah yang cukup besar dan terdiri dari 14 banjar. Seni patung di Singakerta tersebar di beberapa banjar yaitu banjar Dangin Labak, Banjar Dauh Labak, Banjar Lobong, dan banjar Semana. Patung yang banyak dikerjakan lebih banyak binatang laut seperti ikan lumba-lumba, ikan pai, ikan tuna, kura-kura, dan yang lainnya. Bentuk-bentuk ikan ini sering dikombinasikan dengan batu karang yang ada di dasar laut. Perwujudan patung ini lebih banyak berdiri agar ikan kelihatan sedang meloncat.

Dibukaja jalur Tebongkang, Ubud dan Peliatan menyebabkan desa Singekerta memiliki akses pariwisata yang cukup ramai.Desa Singekerta menjadi kawasan wisata Ubud bagian selatan. Masyarakat Singekerta memanfaatkan jalur ini dengan membuka art shop di sepanjang jalan untuk menjajagkan hasil karyanya. Dari barat sampai timur wilayah Singekerta banyak didapatkan art shop 
yang menjual berbagai jenis patung natural dengan beraneka ragam bentuk. Patung dolpin menjadi identitas patung Singekerta.

\section{Desa Sayan dan Desa Kedewatan}

Desa Sayan dan Desa Kedewatan di kecamatan Ubud tidak ditemukan masyarakatnya yang menekuni seni patung. Dua Desa ini masyarakatnya lebih banyak menekuni bidang seni lukis dan seni batik. Selain pekerjaan tersebut banyak masyarakat yang bekerja sebagai pelaku pariwisata. Desa Sayan dan Desa Kedewatan sebagai kawasan wisata banyak terdapat hotel berbintang dan banyak warga di sekitarnya yang terserap sebagai tenaga kerja.

\section{PEMBAHASAN}

Dari hasil penelitian yang telah dilakukan di beberapa desa di Kecamatan Ubud, banyak hal yang dapat diperoleh berkaitan dengan perkembangan seni patung modern pada masing-masing wilayah maupun seniman penciptanya. Masing-masing wilayah memiliki jenis patung yang berbeda sesuai dengan lingkungannya. Demikian juga seniman memiliki identitas karya yang berbeda sesuai dengan ide, gagasan dan ekspresinya.

Suatu hal yang paling membedakan antara karya patung yang lahir di akademik dengan karya patung yang berkembang di masyarakat adalah teknik beton dan teknik reproduksi. Kedua teknik yang lahir di akademik ini mendapat respon yang sangat positif oleh masyarakat umum msupun masyarakat perajin. Bagi masyarakat perajin teknik reproduksi merupakan suatu hal yang sangat baik untuk dimanfaatkan dalam memproduksi karya terutama karya yang menggunakan material batu padas maupun pasir.

\section{Penerapan Pola-pola Akademik dalam Seni Patung di Kecamatan Ubud}

Sesuai dengan apa yang diuraikan di atas tentang pola-pola seni rupa yang berkembang di akademik yaitu garis, bidang, ruang, warna, tekstur, komposisi, proporsi, kesatuan, irama, dan keseimbangan. Dalam penciptaan karya seni polapola ini selalu menjadi pertimbangan yang matang selain ide, gagasan, teknik dan material.

Dalam penciptaan karya patung yang ada di masyarakat, tanpa disadari pola-pola di atas sudah diterapkan oleh seniman atau perajin, tetapi mereka belum mengetahui istilah tersebut dan menjadi perhatian yang sangat penting dalam penciptaan karya seni rupa. Bagi perajin dalam menciptakan karya yang sifatnya produksi juga tidak lepas dari pertimbangan-pertimbangan unsur-unsur estetika dalam proses pengerjaannya. Dalam penciptaan karya patung minimalis yang dimasyarakat dikenal dengan patung abstrak, proses pengerjaannya juga tidak lepas dengan pertimbangan-pertimbangan estetika.
Beberapa seniman dan perajin yang ada di masyarakat menyatakan bahwa banyak hal yang bisa didapatkan dari akademik walaupun tidak secara langsung. Banyak hal-hal baru yang lahir di akademik walaupun dalam volume yang masih sedikit, tetapi banyak memberikan kontribusi pada perajin untuk mengembangkannya. Hal ini dapat dilihat dari kreativitas perajin maupun seniman untuk menciptakan karya-karya patung yang minimalis piguratif. Sebelumnya perajin belum percaya bahwa karya patung tersebut bisa laku di pasaran.Akademik juga diakuinya sebagai pusat lahirnya ide dan gagasan baru dalam penciptaan karya patung.

\section{Pola-Pola Akademik yang diterapkan pada karya seni patung modern di} Kecamatan Ubud

Dalam penciptaan seni patung oleh seniman maupun perajin yang ada di masyarakat sebaian besar telah menerapkan pola-pola akademik dalam karyanya, namun mereka tidak menyadari bahwa segala pertimbangan yang mereka lakukan dalam penciptaan karyanya merupakan unsur-unsur estetikan dan prinsip-prinsip penciptaan karya seni yang dipelajari di akademik. Adapun pola-pola akademik yang diterapkan dalam karya seni patung modern yang ada di masyarakat adalah: garis, warna, ruang, bidang, tekstur, komposisi, proporsi, kesatuan, keseimbangan irama, harmoni dan pusat perhatian.

\section{Peranan seniman dalam pengembangan pola-pola akademik dalam} karyanya

Seniman dan perajin mempunyai peranan yang cukup besar dalam pengembangan pola-pola akademik dalam karyanya, walaupun sebenarnya mereka telah menerapkan secara tidak langsung. Setelah seniman mengetahui bahwa dalam penciptaan karya harus memperhatikan beberapa unsur seni, maka sebelum mengawali pekerjaannya mereka selalu mempertimbangkan garis, warna, bidang ruang, tekstur yang dikombinasikan dengan prinsip penyusunan seperti komposisi, proporsi, kesatuan keseimbangan, harmoni, dan pusat perhatian.

Dalam penciptaan karya patung murni, segala pertimbangan di atas telah dilakukan oleh seniman yang dipadukan dengan teknik yang sangat tinggi sehingga menghasilkan karya yang sangat bagus dan menarik. Demikian juga halnya dengan penciptaan karya patung modern minimalis, segala pola-pola di atas mutlak diperhatikan karena nilai estetis justru akan muncul dari sana. Bentukbentuk yang sederhana, minimalis, hanya bisa dinilai dari unsur-unsur estetika yang terkandung di dalamnya. 


\section{PENUTUP}

Ada perbedaan yang cukup signifikan antara perkembangan seni patung yang ada di masyarakat dengan seni patung yang ada di akademik. Secara kuantitas, seni patung yang ada di masyarakat lebihcepat berkembang dengan seni patung yang ada di akademik. Hal ini adalah suatu yang sangat wajar karena populasi seniman dan perajin patung yang ada di masyarakat cukup banyak. Perkembangan ini juga disebabkan oleh pariwisata, yang mana seni patung merupakan salah satu produk karya seni yang dimanfaatkan sebagai barang souvenir yang dibawa pulang ke negaranya.

Terdapat saling keterpengaruhan antara karya seni patung yang ada di akademik dengan karya patung yang ada dimasyarakat, baik yang berkaitan dengan ide, bentuk, teknik, finishing, dan tampilan. Banyak mahasiswa mendapatkan suber ide dari karya seni patung yang ada di masyarakat, kemudian diolah dan dikembangkan sesuai dengan kreativitasnya sendiri. Demikian juga seniman dan perajin yang ada di masyarakat juga sering mengintip hal-hal baru yang ada di akademik, kemudian dikembangkan pada karyanya.

Dalam penciptaan karya seni patung, seorang seniman maupun perajin telah menerapkan pola-pola akademik dalam karyanya, namun mereka belum mengetahui istilah yang sebenarnya dan merupakan hal yang sangat penting dalam proses penciptaan. Berbagai pola-pola akademik mendapat perhatian yang cukup tinggi dari para seniman dan perajin di masyarakat dan diterapkan dalam penciptaan seni patung yang bergaya modern dengan bentuk minimalis. Mereka nayadari bahwa nilai estetis yang dimunculkan dalam sebuah karya seni adalah pola-pola seni rupa yang berkembang di akademik.

Seniman mempunyai peranan yang cukup besar dalam pengembangan pola-pola akademik dalam karyanya, walaupun sebenarnya mereka telah menerapkan secara tidak langsung. Demikian juga halnya dengan penciptaan karya patung modern, segala pola-pola di atas mutlak diperhatikan karena nilai estetis justru akan muncul dari sana. Bentuk-bentuk yang sederhana, minimalis, hanya bisa dinilai dari unsur-unsur estetika yang terkandung dalam karya.

Pematung akademik diharapkan bersinergi dengan pematung di masyarakat dan menjadi garda depan dalam melakukan aktivitas pameran, sehingga seni patung tidak tertinggal dengan perkembangan seni rupa lainnya.

\section{DAFTAR PUSTAKA}

Erfahmi, Tesis" Seni Patung Modern Sumatra Barat: dari Ramudin sampai Lisa Widiarti" Pascasarjana, ISI Yogyakarta, 2000.

Geriya, I Wayan. 1996. Pariwisata Dan Dinamika Kebudayaan Lokal, Nasional, Global. Upada Sastra Denpasar.
Kartika, Dharsono Sony. 2004. Seni Rupa Modern. Rekayasa Sains, Bandung.

Linus, I Ketut. 1985. "Beberapa Patung Dalam Agama Hindu”.(Sebuah Pendekatan Arkeologi). UNUD. Denpasar.

Linggih, I Nyoman. 2001. "Patung Dewa Ruci di Persimpangan Jalan". Thesis, Kajian Budaya. UNUD, Denpasar

Muchtar, But. 1985. "Seni Patung dalam kaitannya dengan kehidupan manusia" Pidato pengukuhan jabatan guru besar tetap pada Fakultas Seni Rupa dan Disain Institut Teknologi Bandung.

Read, Herbert. 2000. Seni: Arti dan Problematikanya. Terjemahan Soedarso SP. Duta Wacana University Press, Yogyakarta.

Richardson, John Adkin. 1980. Art: The Way It Is. Prentice Hall inc, New Jersey.

Soedarso. 1992. Seni Patung Indonesia. BP ISI Yogyakarta.

2006. Trilogi Seni: Penciptaan Eksistensi dan Kegunaan Seni. BP ISI Yogyakarta.

Sidik, Fajar. 1979. Desain Elementer. STSRI “ASRI”Yogyakarta

Sidarta, GM.. 1975. Seni Lukis Bali dalam Tiga Generasi. Gramedia, Jakarta

Susanto, Mikke. 2003. Membongkar Seni Rupa. Jendela, Yogyakarta. 2002. Diksi Rupa: Kumpulan Istilah Seni Rupa. Kanisiaus, Yogyakarta

Sutha S, I Wayan. 2007. "Seni Patung Bali Dalam Monumen". Warna, Edisi I, FSRD ISI Denpasar.

Swandi, I Wayan. 1999. "Inovasi Ida Bagus Tilem Dalam Seni Patung Bali”. Thesis. Kajian Budaya UNUD, Denpasar

Widia, I Wayan. 1991. Tinjauan Patung Sederhana Bali. Depertermen P \& K. Dirjen Kebudayaan, Permuseuman Bali.

Lampiran: Transformasi Patung Akademik

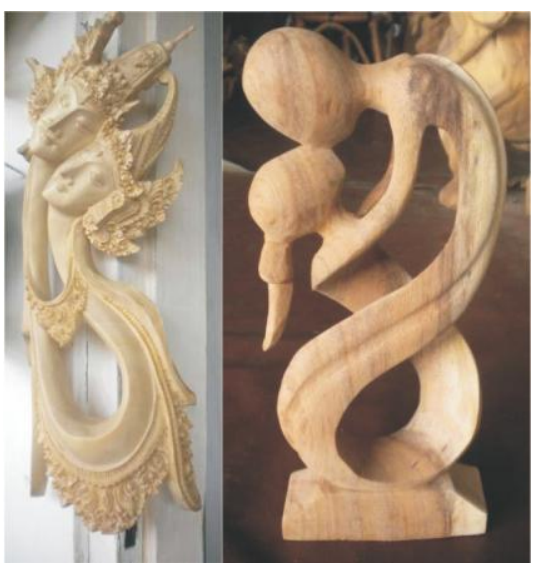

Transpormasi bentuk patung dari tradisi ke minimalis 